\title{
Pacemaker implications in the functional capacity and quality of life of cardiopathic patients
}

\author{
Implicações do marcapasso na capacidade funcional \\ e qualidade de vida de cardiopatas
}

\section{Implicaciones del marcapaso en la capacidad \\ funcional y la calidad de vida de cardiópatas}

\author{
Tainá Samile Pesente ${ }^{[a]} \oplus$, Tiago Luan Labres de Freitas ${ }^{[a]} \oplus$, Jaqueline Piccoli Korb ${ }^{[a]}{ }^{\oplus}$,

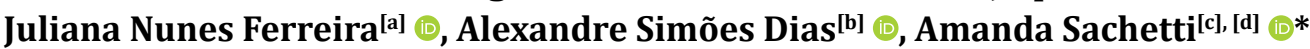 \\ [a] Universidade de Passo Fundo (UPF) e Hospital de Clínicas de Passo Fundo (HCPF), Passo Fundo, RS, Brazil \\ [b] Universidade Federal do Rio Grande do Sul (UFRGS), Porto Alegre, RS, Brazil \\ [c] Universidade de Passo Fundo (UPF), Hospital de Clínicas de Passo Fundo (HCPF), Instituto Meridional (IMED), \\ Passo Fundo, RS, Brazil \\ [d] Universidade Federal do Rio Grande do Sul (UFRGS), Porto Alegre, RS, Brazil
}

\begin{abstract}
Introduction: Cardiovascular diseases are among the main causes of death, and in recent years there has been an increase in pacemaker implants (PM), which is intended not only to increase survival, but also to improve quality of life. Objective: To evaluate the quality of life, cardiorespiratory fitness and level of physical activity of patients before and after permanent PM implant in a large hospital in the north of the state of Rio Grande do Sul. Method: The study comprised 19 patients submitted to PM surgery who had their electronic health record and quality of life (AQUAREL) evaluated as well as their cardiorespiratory fitness and the limit of daily physical activity (VSAQ), peripheral muscle strength (PMS), respiratory muscle strength (manovacuometry), their degree of dyspnea (modified PMS) and the hemodynamic parameters, all of which were assessed in the preoperative period and
\end{abstract}

* TSP: BS, e-mail: tainapsnt@hotmail.com TLLF: BS, e-mail: tiagolabres@hotmail.com JPK: BS, e-mail: jake_piccoli@hotmail.com JNF: BS, e-mail: juhferreirafisio@gmail.com ASD: PHD, e-mail: asdias@hcpa.edu.br

AS: Doctoral Student, e-mail: amandasachetti@gmail.com 
after 30 days. Results: A mean age of 71.79 years was observed and in $63.1 \%$ of the cases Total Atrioventricular Block was the pathology, while $89.5 \%$ of the participants presented systemic arterial hypertension and $31.6 \%$ also presented Diabetes Melittus. Statistically significant improvement was observed in all the values under evaluation, namely: dyspnea $(p=0.0001)$, peripheral muscle strength $(p=0.0001)$ and respiratory muscle strength $\left(\mathrm{PI}_{\mathrm{MAX}} \mathrm{p}=0.0001\right.$ and $\left.\mathrm{PE}_{\mathrm{MAX}} \mathrm{p}=0.0001\right)$, Quality of Life $(\mathrm{p}=0.0001)$ and Cardiorespiratory Fitness and level of physical activity $(p=0.0001)$. Conclusion: Improvement was verified in all parameters analyzed, thus suggesting that the PM positively influences the quality of life and the functionality of the patients.

Keywords: Artificial Pacemaker. Physical Aptitude. Quality of Life. Physiotherapy.

\section{Resumo}

Introdução: As doenças cardiovasculares estão entre as principais causas de mortes, e nos últimos tempos observase aumento nos implantes de marcapasso cardíaco definitivo (MP), sendo que esse visa não apenas aumentar a sobrevida, mas também a qualidade de vida. Objetivo: Avaliar a qualidade de vida, a aptidão cardiorrespiratória e nível de atividade física de pacientes antes e após o implante de MP em um hospital de grande porte do norte do estado do Rio Grande do Sul. Método: O estudo contou com 19 pacientes submetidos ao MP, onde avaliou-se o prontuário eletrônico, a qualidade de vida (AQUAREL), a aptidão cardiorrespiratória e o nível limite de atividade física diária (VSAQ), a força muscular periférica (MRC), a força muscular respiratória (manovacuometria) o grau de dispneia (MRC modificado) e os parâmetros hemodinâmicos, sendo esses avaliados no pré-operatório e após 30 dias. Resultados: Observou-se média de idade de 71,79 anos, a patologia que levou ao procedimento em 63,1\% dos casos foi o Bloqueio Atrioventricular Total, 89,5\% dos participantes eram portadores de Hipertensão Arterial Sistêmica e $31,6 \%$ de Diabetes Melittus. Observou-se melhora estatisticamente significativa em todos os nos valores analisados, sendo eles: dispneia ( $p=0,0001)$, força muscular periférica $(p=0,0001)$ e respiratória (PIMÁX $p=0,0001$ e PEMÁX $p=0,0001)$, Qualidade de Vida ( $p=0,0001)$ e Capacidade cardiorrespiratória e nível de atividade física $(p=0,0001)$. Conclusão: Verificamos melhora em todos os parâmetros analisados, podendo assim sugerir, que o MP influência positivamente na qualidade de vida e na funcionalidade dos portadores.

Palavras-chave: Marca-passo Artificial. Aptidão Física. Qualidade de Vida. Fisioterapia.

\section{Resumen}

Introducción: Las enfermedades cardiovasculares están entre las principales causas de muertes, y en los últimos tiempos se observa un aumento en los implantes de marcapaso cardíaco definitivo (MP), siendo que no sólo pretende aumentar la supervivencia, sino también la calidad de vida. Objetivo: Evaluar la calidad de vida, la capacidad cardiorrespiratoria y nivel de actividad física de pacientes antes y después del implante de MP en un hospital de gran porte del norte del estado de Rio Grande do Sul. Métodos: El estudio contó con 19 pacientes que se sometieron al MP, en que se evaluó el registro electrónico, la calidad de vida (AQUAREL), la capacidad cardiorrespiratoria y el nivel límite de actividad física diaria (VSAQ), la fuerza muscular periférica (MRC), la fuerza muscular respiratoria (manovacuometría), el grado de disnea (MRC modificada) y los parámetros hemodinámicos, siendo estos evaluados en el preoperatorio y después de 30 días. Resultados: Se observó un promedio de edad de 71,79 años, la patología que llevó al procedimiento en el 63,1\% de los casos fue el Bloqueo Atrioventricular Total, el 89,5\% de los participantes eran portadores de Hipertensión Arterial Sistémica y el 31,6\% de Diabetes Melittus. Se observó una mejora estadísticamente significativa en todos los valores analizados, siendo ellos: disnea ( $p=0,0001)$, fuerza muscular periférica $(p=0,0001)$ y respiratoria (PIMÁX $p=0,0001$ y PEMÁX $p=0,0001)$, Calidad de Vida $(p=0,0001)$ y Capacidad cardiorrespiratoria y nivel de actividad física ( $p=0,0001)$. Conclusión: Verificamos una mejoría en todos los parámetros analizados, pudiendo así sugerir que el MP influye positivamente en la calidad de vida y en la funcionalidad de los portadores.

Palabras clave: Marcapaso Artificial. Aptitud Física. Calidad de Vida. Fisioterapia. 


\section{Introduction}

Cardiovascular diseases are in the group of nontransmittable chronic diseases (NTCD) and are among the main causes of death in the world, considering that in the South of Brazil cardiovascular diseases (CVD) are responsible for around $32.1 \%$ of deaths and have become a current public health issue [1] .

Relevant changes have been observed in the recent life and health conditions of the population, since it has grown older and has been exposed to different patterns of work and leisure, in addition to deep changes in the quality and amount of food intake. The contemporary lifestyle along with habits adopted by the population such as smoking, unsuitable diet, excessive alcohol consumption, emotional stress and a sedentary routine, all contribute to the appearance of hyperglycemia, dyslipidemia, arterial hypertension and obesity, and several studies have pointed them out as main risk factors for the development of $\operatorname{CVD}[2,3]$.

When an increase is seen in CVD, an increase is also observed in the occurrence of cardiac procedures, high prevalence of this kind of treatment is observed and the most common procedures are myocardial revascularization surgeries and valve procedures [4]. The permanent cardiac pacemaker implant (PM) has increased in the last few years with the purpose of treating bradyarrhythmia, Atrioventricular blocks (AVB) (second degree or total), sinus node disease, high ventricular frequency atrial fibrillation and neuro-mediated syndromes [5-7]. PM implants aim at increasing patients' survival and also their quality of life, adjusting the heart rate to their metabolic needs, lengthening their lifespan and allowing them to carry out their daily activities, which were previously limited [8-10].

The fast development, in the last few decades, of sophisticated devices and the increase in the number of referrals to PM implants call attention to the use of measurements that evaluate quality of life and the level of functionality of these patients, since previous studies have already demonstrated the negative correlation between quality of life and the functional classification of patients submitted to PM [11]. The PM implant is believed to result in improvements to the patient's life however, up to now, very little has been investigated about their functionality after implant. For this reason, the objective of our study was to evaluate these patients' quality of life, their cardiorespiratory fitness and level of physical activity and through them their functional capacity before and after PM implant in a large hospital in the north of the State of Rio Grande do Sul.

\section{Methods}

This is a transversal and quali-quantitative study carried out in a large hospital in the north of the state of Rio Grande do Sul (RS), with a sample comprising of 19 patients of both genders submitted to PM implant. The data were collected from April to October 2017 and the sample was limited by the time of the research. The inclusion criteria in this study were patients admitted in the hospital for PM implant that agreed to sign the Informed Consent (TCLE), older than 18 years old, without limit of maximum age, of both genders, who were authorized by their physician to take part in the study. The exclusion criteria were: patients that presented physical-functional limitations that prevented them from taking part in the evaluation tests, patients with cognitive issues that could not understand the tests or presented clinical decompensation during the evaluations, patients with neuromuscular and/or neurological diseases. Individuals that already had records of other cardiac procedures in their background were not excluded.

The evaluation was carried out through the following procedures:

- Electronic health record analysis: Obtaining sociodemographic data and information about their current and previous diseases to identify the type of pathology that led to the cardiac procedure and to identify the frequency of comorbidities.

- Quality of Life Assessment: It was carried out through the quality of life questionnaire Assessment of Quality of Life and Related Events (AQUAREL), specific for the evaluation of quality of life of pacemaker patients, in its Portuguese version, published and validated in 2006 . The questionnaire contains 20 questions directly linked to relevant aspects of this type of patients, distributed into three groups: chest discomfort, arrhythmia and dyspnea. Each question presents five possibilities of answers, with values varying from 1 to 5 . The values obtained vary from zero to a hundred, the latter represents perfect quality of life. [12].

- Questionnaire to evaluate cardiorespiratory fitness and the limitlevel of daily physical activity: 
The Veterans Specific Activity Questionnaire (VSAQ) was applied. This instrument is used to calculate the cardiorespiratory fitness and the limit level of daily physical activity carried out that leads to the appearance of cardiovascular symptoms. It consists of a list of activities presented in a progressive order according to their metabolic equivalents (METS) [13].

- Evaluation of peripheral muscle strength: It was assessed by the Medical Research Council protocol (MRC), which evaluates and grades strength in values between 0 (total palsy) and 5 (normal muscle strength) through the voluntary performance of six specific bilateral movements. The total score might vary from 0 (complete tetraparesis) to 60 (normal muscle strength) [14].

- Evaluation of respiratory muscle strength: The respiratory muscle strength was assessed through manovacuometry, using a digital MVD 300 Globalmed manovacuometer. Maximum inspiratory pressure $\left(\mathrm{PI}_{\mathrm{MAX}}\right)$ and maximum expiratory pressure $\left(\mathrm{PE}_{\mathrm{MAX}}\right)$ were evaluated. $\mathrm{PI}_{\mathrm{MAX}}$ was obtained through a maximum inspiration manoeuvre starting from a maximum expiration, close to the Residual Volume (RV), while $\mathrm{PE}_{\mathrm{MAX}}$ was measured from a maximum expiration manoeuvre starting from a maximum inspiration close to the Total Lung Capacity (TLC). The measurements were carried out three times, and the highest value obtained was considered [15].

- Degree of dyspnea: The modified Medical Research Council scale was used to characterize the patients' degree of dyspnea. The modified MRC score varies from 0 to 4 degrees, where each degree represents the Dyspnea sensation, in which degree 0 means: I have difficulties breathing when carrying out intense exercises, Degree 1: I have difficulties breathing when I walk fast, go up the stairs or up the hill. Degree 2: I need to stop some times when I walk in my normal speed or even slower than other people my own age. Degree 3: I need to stop several times due to lack of air when I walk around 100 meters, or after a few minutes of walk on a flat surface. Degree 4: I feel so breathless that I do not go out and even need help to dress myself or have a shower [16].

- Verification of hemodynamic parameters: Blood pressure, heartand breathing rate were measured as well as the oxygen peripheral saturation.
The participants were submitted to pre-surgery tests when admitted in the hospital, 24 hours prior do the PM implant and after 30 days of the PM implant surgery when returning to see their physician. This study followed the Resolution $n^{\circ} 466$ of $12^{\text {th }}$ December 2012 by the Health National Council of the Health Ministry and approved by the Research Ethics Committee of the Passo Fundo University through the Opinion $\mathrm{n}^{\mathrm{o}}$ 1.988.607on $29^{\text {th }}$ March 2017. The data analysis was aided by the statistical program Statistical Package for the Social Sciences (SPSS) 23.0 descriptive statistics and the Student's $t$ test for paired samples was used considering values $p<0.05$ for statistical significance and the Pearson correlation test for the analysis of correlations between variables.

\section{Results}

This study comprised a sample of 19 individuals of both genders submitted to PM. The sample mean age was 71.79 years old ( $D P \pm 9.13$ ), and $52.6 \%$ of the participants were male, with a mean BMI of $26.01 \mathrm{~kg} / \mathrm{m}^{2}$ (DP $\pm 4,14$ ), $68.4 \%$ of the cases received treatment through the National Health System. Regarding the participants' jobs, $36.8 \%$ were housewives, $21 \%$ business owners, $15.8 \%$ farmers, $10.5 \%$ worked in the metallurgic industry and another $15.8 \%$ had different jobs. When schooling was assessed, the data showed that $52.4 \%$ had not completed elementary school.

The analysis of the clinical diagnosis showed that the main cause of the implants, $63.1 \%$ of the cases was $\mathrm{CHB}$, while the cause in $21.1 \%$ of the cases was $2^{\text {nd }}$ degree $\mathrm{CHB}, 10.4 \%$ were caused by high response atrial fibrillation and another $5.3 \%$ presented Tachy-Brady Syndrome. The investigation of associated diseases revealed that $89.5 \%$ of the participants presented Systemic Arterial Hypertension (SAH), 31.6\% had Diabetes Melittus (DM), 15.8\% presented Chronic Obstructive Pulmonary Disease, $21.1 \%$ were smokers and $31.6 \%$ had high levels of triglycerides.

From the total number of patients analyzed, $36.7 \%$ presented 1 or 2 associated diseases, while $21.5 \%$ had from 3 to 4 associated diseases. The mean of two days in hospital was 5.6 (DP $\pm 4,56$ ), but most of the patients were discharged on the first day after surgery, no post-surgery complications were observed. 
The aim of this study was to evaluate the quality of life before and after the pacemaker implant. The findings are described in Table 1.

Other factors analyzed were dyspnea, peripheral and lung muscle strength in addition to cardiorespiratory fitness and level of physical activity. The results obtained for these variables can be seen in Table 2 .

Regarding hemodynamic parameters, the values obtained for those variables pre and post PM implant are shown in Table 3.
When analyzing the Aquarel and VSAQ questionnaires of patients who presented up to two comorbidities and over three comorbidities, the results showed that the higher the number of associated illnesses, the lower the questionnaire scores. The Aquarel presented $71 \pm 9.14$ versus $89 \pm 18.5$, with $p 0.673$, while the figures of VSAQ were $3.05 \pm 0.28$ versus $5.41 \pm 1.34$, with $p$ 0.039. Also, the Aquarel questionnaires for QL and CCRNAF were correlated to IMS and EMS as shown in Table 4.

Table 1 - Quality of life analyzed using the Aquarel questionnaire pre and post-pacemaker implant

\begin{tabular}{lccl}
\hline QL Criteria & Pre-implant & Post-implant & p values \\
\hline Chest discomfort & $40.89(\mathrm{DP} \pm 13.68)$ & $83.94(\mathrm{DP} \pm 12.98)$ & $0.0001^{*}$ \\
Dyspnea & $40.21(\mathrm{DP} \pm 13.47)$ & $83.57(\mathrm{DP} \pm 9.91)$ & $0.0001^{*}$ \\
Arrhythmia & $46.36(\mathrm{DP} \pm 13.34)$ & $85.26(\mathrm{DP} \pm 7.60)$ & $0.0001^{*}$ \\
Total & $42.63(\mathrm{DP} \pm 12.29)$ & $83.21(\mathrm{DP} \pm 10.01)$ & $0.0001^{*}$ \\
\hline
\end{tabular}

Note: QL: Quality of life (measured in points). ${ }^{*} p<0.05$ compared to the initial data (Student $t$ test for paired samples).

Table 2 - Degree of dyspnea, peripheral and lung muscle strength, cardiorespiratory fitness and level of physical activity of the participants pre and post-pacemaker implant

\begin{tabular}{lccc}
\hline QL Criteria & Pre-implant & Post-implant & p values \\
\hline Dyspnea & $3.10(\mathrm{DP} \pm 0.73)$ & $1.63(\mathrm{DP} \pm 0.49)$ & $0.0001^{*}$ \\
PMS & $53.68(\mathrm{DP} \pm 6.15)$ & $57.47(\mathrm{DP} \pm 4.61)$ & $0.0001^{*}$ \\
IMS & $-39.26(\mathrm{DP} \pm 9.60)$ & $-50.89(\mathrm{DP} \pm 7.86)$ & $0.0001^{*}$ \\
EMS & $+48.15(\mathrm{DP} \pm 10.78)$ & $+57.89(\mathrm{DP} \pm 8.04)$ & $0.0001^{*}$ \\
CRFPAL & $3.14(\mathrm{DP} \pm 1.22)$ & $4.92(\mathrm{DP} \pm 1.57)$ & $0.0001^{*}$ \\
\hline
\end{tabular}

Note: Dyspnea (measured in degrees). PMS: peripheral muscle strength (degrees). IMS: Inspiratory muscle strength $\left(\mathrm{cmh}_{2} 0\right)$. EMS: expiratory muscle strength $\left(\mathrm{cmh}_{2} 0\right)$. CRFPAL: cardiorespiratory fitness. Physical activity level (METS). ${ }^{*} p<0.05$ compared to the initial data (Student $\mathrm{t}$ test for paired samples).

Table 3 - Hemodynamic parameters pre and post-pacemaker implant

\begin{tabular}{lccc}
\hline \multicolumn{1}{c}{ Parameters } & Pre-implant & Post-implant & p values \\
\hline BP & Systolic: $130(\mathrm{DP} \pm 20)$ & Systolic: $124(\mathrm{DP} \pm 12)$ & $0.0188^{\star}$ \\
& Diastolic: $75(\mathrm{DP} \pm 17)$ & Diastolic: $67(\mathrm{DP} \pm 5)$ & 0.1124 \\
HR & $36.73(\mathrm{DP} \pm 5.09)$ & $74.84(\mathrm{DP} \pm 4.16)$ & 4.3675 \\
RR & $17.26(\mathrm{DP} \pm 3.07)$ & $14.78(\mathrm{DP} \pm 1.98)$ & $0.0036^{\star}$ \\
Sp02 & $95.78(\mathrm{DP} \pm 2.61)$ & $96.63(\mathrm{DP} \pm 2.77)$ & 1.6388 \\
\hline
\end{tabular}

Note: BP: Blood pressure (mmhg). HR: heart rate (bpm). RR: Respiratory rate (ipm). Sp02: oxygen peripheral saturation (\%). * $p<0.05$ compared with initial data (Student t test for paired samples).

Table 4 - Correlation between variable pre and post pacemaker implant

\begin{tabular}{lcc}
\hline Variables & Correlation & p value \\
\hline QL and CRFLPA & $0.4133^{*}$ & 1.1359 \\
IMA and CRFLPA & $0.5294^{*}$ & 6.9565 \\
SEM and CRFLPA & $0.3697^{* *}$ & 4.7438 \\
\hline
\end{tabular}

Note: QL and CRFLPA: Quality of life and Cardiorespiratory fitness and level on physical activity. IMS and CRFLPA: Inspiratory Muscle Strength and Cardiorespiratory Fitness and level of physical activity. ESM and CRFLPA: Expiratory Muscle Strength and Cardiorespiratory Fitness and level of Physical Activity. ${ }^{*}$ Demonstrating moderate co-relation between the values. ${ }^{* *}$ Demonstrating weak co-relation between the values. 


\section{Discussion}

When analyzing the participants' profile, most were elderly men, around $89 \%$ of the participants presented SAH and over 31\% had DM. The pathology leading to the implant in $84.2 \%$ of the cases was atrioventricular block. The data in this study confirmed that of other studies that observed the predominance of male patients, who were around 70 years old and presented high prevalence of SAH and DM. The most reported diagnosis in the literature leading to this procedure was atrioventricular block $[17,11,18]$.

Regarding the presence of atrioventricular block that led to the implant in $84.2 \%$ of the cases, this data is also confirmed by the data published by the Pacemaker Brazilian Register which shows that $65.4 \%$ of the referrals to this kind of surgery are caused by atrioventricular block, followed by the sinus node illness in $29 \%$ of the cases and $4.9 \%$ due to other indications $[19,6]$.

One of the main objectives of this study was to evaluate the functional capacity and level of physical activity of the patients. Low levels of these variables were observed both pre and postimplant. However, the post-implant improvement was considered statistically significant. Before PM implant, the results were around 3.14 (DP \pm 1.22 ) METS representing, according to the questionnaire, that the maximum activity that the patient could develop without triggering any symptoms such as chest discomfort, tiredness and breathing difficulties was "walking slowly on a flat surface, or two blocks or developing domestic activities such as sweeping the floor and vacuuming", while in the post-surgery period, there was a significant improvement of this variable to 4.92 (DP \pm 1.57 ) METS, showing that the patients could even carry out "light tasks in the yard, some works of carpentry and light painting". Taking into consideration the patients' mean age in this study (71.79 years old DP \pm 9.13 ), one could suggest that the implant resulted in greater functional autonomy for these patients, since they could develop more intense activities. The literature already points out that in addition to prolonging patients' lives the pacemaker recovers the patients' functionality, since it allows them to carry out daily activities, which was a limitation they presented before the surgery [18, 20-23].
A study sought to evaluate quality of life through the SF-36 questionnaire after six months of the pacemaker implant, when the item's functional capacity was analyzed, it resulted in 69.2 points, demonstrating those patients' good functional capacity [23]. Another study that evaluated the frailty of 117 patients before the implant of this device and compared with quality of life observed that patients considered weak showed lower levels of quality of life, when they were evaluated again after six months, they showed improvement in quality of life in all weak patients [24]. A study aiming at evaluating the functional capacity of 61 children and young adults who had been submitted to chronical pacemaker implant and evaluated its correlation with the ventricular remodelling, in which the functional capacity was evaluated through the 6-minute walking test, showed that the mean distance covered was strongly correlated to the predicted distance, demonstrating those patients' good functional capacity after PM implant [25].

The quality of life analysis was carried out by observing individual characteristics and the questionnaire total score. Regarding individual characteristics, in the pre-implant phase, both dyspnea and chest discomfort and arrhythmia presented low score, representing bad quality of life, in which the symptoms interfered in the individual's everyday life. Also in the pre-implant phase, the total score confirmed this information. While in the post-implant phase, the scores were seen to increase regarding both individual characteristics and final score, which was considered good quality of life. The literature presents some discussions on the quality of life of patients submitted to implants, in one of these studies, which analyzed quality of life using the AQUAREL questionnaire, after six months of the implant surgery, dyspnea presented a score of 75 points, while arrhythmia had a score of 89 points and chest discomfort a score of 90.8-points, with a total score of 84.9 points. Such reports show, as in this study, high levels of quality of life after pacemaker implant.

This study also evaluated the patients' quality of life using the SF-36 questionnaire and observed a suitable perception of quality of life through this questionnaire [16]. Another study that also used SF36 and AQUAREL questionnaires observed that none of the items investigated presented results 
with values below 50 , and in general the perceived quality of life of those patients was good [9].

Some studies seek to co-relate quality of life and the functional capability of PM patients, in this study a moderate correlation was observed between these variables. Another study observed a negative correlation between functional category and quality of life, suggesting that those individuals that belonged to a better functional category presented better quality of life scores [11]. A controlled clinical test evaluated quality of life and functional capacity pre and post-PM implant related to the health of 82 patients and observed improvement in their quality of life and the maintenance of their functional capacity throughout 12 months [26].

An important fact observed in this study was the 5.6-day mean permanence in the hospital, which is considered low for a surgical procedure. No postsurgical complications were observed in the cases under study. Authors in general already consider pacemaker implant a simple and fast procedure $[21,24]$. A study that aimed at evaluating the index of complications associated to PM surgery and Implantable Cardioverter Defibrillator (ICD) analyzed 1,242 procedures and observed that in only $5.71 \%$ of the cases there were complications, and the most common was bruise. They concluded that procedures of PM implant and change and ICD are associated to low complication indices $[27,28]$.

The analysis of hemodynamic parameters revealed a normal blood pressure mean, both before and after implant, as well as breathing rate and oxygen peripheral saturation. While the heart rate before the procedure was found to be around 36.73 (DP \pm 5.09 )bpm, demonstrating the need of intervention to keep the cardiac effectiveness and functionality. The literature points out that the pacemaker enables improvement of the patients' clinical and hemodynamic response, by keeping and correcting the heart rate [25]. Thus, after 30 days of the implant, significant improvement in the heart rate is generally observed. The pacemaker adjusts the heart rate to the user's metabolic needs, prolonging their lives and allowing them to carry out daily activities, which were limited before the procedure [9].

The levels of dypnea, evaluated by the modified MRC, showed significant increase in the values after the implementation of the device. For example, before the implant difficulty in breathing was classified with mean 3.1 ( $\mathrm{DP} \pm 0.73$ ), indicating that the patient "needed to stop many times due to difficult breath when they walked around 100 meters, or a few minutes on a flat surface". However, in the re-evaluation, a 1.63 (SD \pm 0.49 ) mean was observed. Such value is statistically significant $(\mathrm{p}=0.0001)$, indicating that the individual "had difficulties breathing when they tried to walk faster, or went up the stairs or a hill". In a study that analyzed 84 pacemaker users after six months of implant observed that around $70 \%$ of the participants no longer felt dyspnea when going up the stairs or a hill or if they felt it, it was only slightly. Regarding walking on a flat surface, $50 \%$ no longer felt breathless, while $47 \%$ no longer had difficulties breathing when doing physical activities [29].

The peripheral muscle strength, evaluated using the MCR protocol, was seen to be normal both before and after PM implant. This fact suggests that the difficulty to carry out activities was not the result of decrease in the muscle strength, it resulted from hemodynamic alterations caused by the cardiac disorder. Regarding respiratory muscle strength, evaluated through manovacuometry, lower values were observed before the implant, while statistically significant improvement in the values was observed after implant. A study evaluated peripheral and respiratory muscle strength of patients with cardiac insufficiency and observed reduction in the inspiratory and expiratory muscle strength and the lower limbs, only observing normal strength in the upper limbs. The same study correlated the reduction in the lower limb strength with the patients' functional limitation and observed that individuals that presented reduction in the lower limb strength showed lower levels of functionality [30].

\section{Conclusion}

The results obtained based on the parameters evaluated led to the conclusion that permanent pacemaker implant resulted in improvement in the patients' quality of life, functionality, peripheral and respiratory muscle strength and increase in dyspnea, due to the adjustment of the heart rate to the metabolic needs. These results aid the physiotherapist in the role of rehabilitator guiding conducts and enabling the search for the patient's full recovery. 


\section{References}

1. Soar C. Prevalência de fatores de risco cardiovascular em idosos não institucionalizados. Rev Bras Geriatr Gerontol. 2016;18(2):385-95.

2. Roas YAS, Reis EJB. Causas e conseqüências de um estilo de vida sedentário e possibilidades de transformar a o conhecimento de hábitos saudáveis em ações práticas e concretas. EFDeportes. 2012;17(168):65-8.

3. Muniz LC. Fatores de risco comportamentais acumulados para doenças cardiovasculares no sul do Brasil. Rev Saude Publica. 2012;46(3):534-42.

4. Monteiro GM, Moreira DM. Mortalidade em Cirurgias Cardíacas em Hospital Terciário do Sul do Brasil. Int J Cardiovasc Sci. 2015;28(3):200-5.

5. Teno LAC, Costa R, Martinelli Filho M, Castilho FCT, Ruiz I, Stella UB, et al. Efeitos da mudança de modo de estimulação ventricular para atrioventricular sobre a qualidade de vida em pacientes com cardiopatia chagásica e bloqueio atrioventricular na troca eletiva do gerador de pulsos. Rev Bras Cir Cardiovasc. 2010;20(1):23-32.

6. Silva AM, Rocha A, Melo CS, Silva Jr O., Kanaan EE, Baccaglini WRC, et al. Alterações anatomopatológicas de corações de pacientes chagásicos portadores de marca-passo definitivo endocárdico. Relampa. 2013;26(1):3-12.

7. Ramos G, Filho JR, Júnior AR, Pereira E, Neto SG, Chaves E. Marcapasso cardíaco artificial: considerações pré e per-operatórias. Rev Bras Anestesiol. 2003;53(6):854-62.

8. Kanaan EE, Salvado PR, Franco MC, Melo CS, Paiva TCN, Melo GRS. Ablação de arritmias cardíacas por radiofrequência em pacientes portadores de marcapasso cardíaco definitivo e cardiodesfribriladores implantáveis. Relampa. 2013;26(1):29-32.

9. Borges JBC, Barros RT, Carvalho SMR, Silva MAM. Correlação entre a qualidade de vida, classe funcional e idade em portadores de marca-passo cardíaco. Rev Bras Cir Cardiovasc. 2013;28(1):47-53.
10. Salgado C. Tratado de estimulação cardíaca artificial. 5. ed. Barueri: Manole; 2015.

11. Cunha TMB, Cota RMA, Souza BK, Oliveira BG, Ribeiro ALP, Sousa LAP. Correlação entre classe funcional e qualidade de vida em usuários de marcapasso cardíaco. Rev Bras Fisioter. 2007;11(5):341-5.

12. Oliveira BG, Melendez JGV, Ciconelli RM, Rincón GL, Torres AAS, Sousa LAP, et al. Versão em português, adaptação transcultural e validação de questionário para avaliação da qualidade de vida para pacientes portadores de marcapasso: AQUAREL. Arq Bras Cardiol. 2006;87(2):75-83.

13. Maranhão-Neto GA, Leon ACP, Farinatti PTV. Validade e equivalência da versão em português do Veterans Specific Activity Questionnaire. Arq Bras Cardiol. 2011;97(2):130-5.

14. Medical Research Council. Aids to the investigation of peripheral nerve injuries. London: Her Majestys Stationery Office; 1976.

15. Onaga FI, Jamami M, Ruas G, Di Lorenzo VAP, Jamami LK. Influência de diferentes tipos de bocais e diâmetros de traqueias na manovacuometria. Fisioter Mov. 2010;23(2):211-9.

16. Kovelis D, Segretti NO, Probst VS, Lareau SC, Brunetto AF, Pitta F. Validation of the Modified Pulmonary Functional Status and Dyspnea Questionnaire and the Medical Research Council scale for use in Brazilian patients with chronic obstructive pulmonary disease. J Bras Pneumol. 2008;34(12):1008-18.

17. Barros RT, Carvalho SM, Silva MA, Borges JB. Evaluation of patients' quality of life aspects after cardiac pacemaker implantation. Rev Bras Cir Cardiovasc. 2014;29(1):37-44.

18. Brasil VV. Qualidade de vida do portador de marcapasso cardíaco definitivo: antes e após implantes. Rev Eletronica Enferm. 2002;4(1):64-9.

19. Mateos JCP, Pereira WL, Batista WD Jr, Mateos JCP, Mateo EIP, Vargas RNA, et al. Registro Brasileiro de Marcapassos, Ressincronizadores e Desfibriladores. Relampa. 2013;26(1):39-49. 
20. Frota MA, Falcão PV, Santos ZMSA. Paciente Portador de Marcapasso Cardíaco e seu Estilo de Vida. Esc Anna Nery Rev Enferm. 2007;11(2):234-9.

21. Brasil VV, Cruz LM. Alterações nos hábitos de vida relatadas por portadores de marcapasso definitivo. Relampa. 2000;13(2):97-113.

22. Chistmann M, Costa CC, Moussalle LD. Avaliação da qualidade de vida de pacientes cardiopatas internados em um hospital público. Rev AMRIGS. 2011;55(3):239-43.

23. Gomes TB, Gomes LS, Antonio IHF, Barroso TL, Cavalcante AMRZ, Stival MM, et al. Avaliação da qualidade de vida pós-implante de marca-passo cardíaco artificial. Rev Eletronica Enferm. 2011;3(4):11-25.

24. Bergmann ARN, Souza LL, Scorsolini-Comin F, Santos MA. A vida por um fio: percepções sobre o implante de marca-passo cardíaco permanente. Rev Subj. 2016;16(1):131-43.

25. Oliveira RM Jr, Silva KR, Kawauchi TS, Alves LBO, Crevelari ES, Filho MM, et al. Functional capacity of patients with pacemaker due to isolated congenital atrioventricular block. Arq Bras Cardiol. 2015;104(1):67-77.

26. Lopez-Villegas A, Catalan-Matamoros D, Robles-Musso E, Peiro S. Effectiveness of pacemaker tele-monitoring on quality of life, functional capacity, event detection and workload: the PONIENTE trial. Geriatr Gerontol Int. 2016;16(11):1188-95.

27. Mlynarska A, Mlynarski R, Golba KS. Influence of frailty on the quality of life patients qualified for pacemaker implantation. J Clin Nurs. 2018;27(3-4):555-60.

28. Silva O Jr, Melo CS, Marra M, Tomaz AA, Nunes DA. Complicações associadas a cirurgias de implante e troca de dispositivos cardíacos eletrônicos implantáveis (DCI) em chagásicos. Relampa. 2009;22(2):57-71.

29. Zatta LT. Avaliação da qualidade de vida de portadores de marcapasso cardíaco artificial em Goiânia. [master's thesis]. Goiás: Universidade Federal de Goiás; 2010.
30. Chiodelli GC, Araujo CLP, Reis CM, Fonseca FR, Karloh M, Mayer AF. Relação das forças musculares respiratória e periférica com a limitação funcional em pacientes com insuficiência cardíaca. Rev Bras Cienc Mov. 2015;23(1):136-45.

Received in 01/30/2018

Recebido em 30/01/2018

Recibido en 30/01/2018

Approved in 07/05/2019

Aprovado em 05/07/2019

Aprobado en 05/07/2019 